\title{
No evidence of spatial root system segregation and elevated fine root biomass in multi-species temperate broad-leaved forests
}

\author{
Catharina Meinen · Christoph Leuschner • \\ Nicholas T. Ryan · Dietrich Hertel
}

Received: 12 August 2008/Revised: 2 April 2009/Accepted: 8 April 2009/Published online: 9 May 2009

(C) The Author(s) 2009. This article is published with open access at Springerlink.com

\begin{abstract}
Differences in spatial rooting patterns among coexisting species have been recognized as an important mechanism for generating biodiversity effects on ecosystem functioning. However, it is not yet clear whether complementarity in root space exploration is a universal characteristic of multi-species woody communities. In a temperate broad-leaved forest with a mosaic of speciespoor and species-rich stands, we tested two hypotheses related to putative below-ground 'overyielding' in more diverse forests, (1) that species mixture results in a partial spatial segregation of the fine root systems of different species, and (2) that stand fine root biomass increases with tree species diversity. We investigated 12 stands either with one, three, or five dominant tree species (4 replicate stands each) under similar soil and climate conditions for stand fine root biomass and spatial root segregation in vertical and horizontal direction in the soil. Fine roots of different tree species were identified using a morphological key based on differences in colour, periderm surface structure, and branching patterns. In species-poor and species-rich stands, and in all tree species present, fine root density (biomass per soil volume) decreased exponentially with soil depth at very similar rates. Stand fine root biomass in the densely rooted upper soil $(0-40 \mathrm{~cm}$ depth) was not
\end{abstract}

Communicated by M. Adams.

C. Meinen · C. Leuschner $(\bowtie) \cdot D$. Hertel

Plant Ecology, University of Göttingen,

Untere Karspüle 2, 37073 Göttingen, Germany

e-mail: cleusch@gwdg.de

N. T. Ryan

Department of Plant, Soil, and Insect Sciences, University of Massachusetts, 101 Fernald Hall, Amherst, MA 01003, USA significantly different between stands with 1,3 or 5 dominant tree species. We conclude that 'below-ground overyielding' in terms of higher fine root biomasses in species-rich stands as compared to monospecific ones does not occur in these broad-leaved forests which most likely results from a missing complementarity in vertical rooting patterns of the present tree species.

Keywords Below-ground diversity - Complementarity . Fagus - Fraxinus Mixed stands $\cdot$ Niche partitioning · Overyielding $\cdot$ Tilia

\section{Introduction}

Evidence from experiments with artificially designed grasslands suggests that above-ground plant biomass and productivity may increase with increasing numbers of plant species and/or plant functional types present (Hooper and Vitousek 1997; Tilman et al. 1996, 1997; Hector et al. 1999; Spehn et al. 2000; Loreau and Hector 2001; Hooper and Dukes 2004). One explanation of this 'overyielding' phenomenon is complementary use of light, water or nutrients by the component species (Loreau 1998; Hooper et al. 2005; Cardinale et al. 2007; Yachi and Loreau 2007). Such complementarity effects have been not only described for grassland systems (e.g. von Felten and Schmid 2008), but have been frequently used in agricultural systems to obtain higher yields and sustainable resource use through intercropping or in agroforestry systems (Ewel 1999; Grierson and Adams 1999; Droppelmann et al. 2000a, b).

Beside the general acknowledgement of the meaning of complementarity in light capture for above-ground productivity (e.g. Menalled et al. 1998; Ewel and Mazzarino 2008), a number of authors have emphasized the importance of 
below-ground complementarity of species for their coexistence and for diversity effects on ecosystem functioning (e.g. Hooper and Vitousek 1997; Loreau 1998; Pate and Bell 1999; Ewel and Mazzarino 2008). Species' complementarity in the root system has been demonstrated in particular for tropical agroecosystems (e.g. Huxley et al. 1994; Ewel 1999; Grierson and Adams 1999; Droppelmann et al. 2000a, b). In contrast, the spatial arrangement of plant root systems and their water and nutrient uptake activity in monospecific and mixed natural forest ecosystems have only rarely been studied. Thus, the physiological basis for possible overyielding in species-rich forest communities is not well understood for the below-ground compartment. This is especially true for temperate forests, which only recently have been included in the search for the ecological functions of biodiversity (Scherer-Lorenzen et al. 2007). The lack of such studies in temperate forests that are often built by a limited number of dominant tree species is unsatisfactory since marked effects of increasing plant diversity on ecosystem functions are expected particularly in plant communities with relatively small numbers of species (Vitousek and Hooper 1993; Jolliffe 1997).

While we are aware of no study that has compared fine root production in mixed and monospecific forest stands, a number of investigations found a higher fine root biomass in mixed stands (Schmid 2002; Schmid and Kazda 2002); others, however, reported no differences or the opposite (Morgan et al. 1992; Hendriks and Bianchi 1995; Hertel 1999; Bauhus et al. 2000; Leuschner et al. 2001; Bolte and Villanueva 2006). Most of these studies referred to twospecies stands, while species-rich forests have only rarely been investigated for their root systems. One reason is the difficult identification of tree species by their fine roots, which hinders the analysis of species-specific root distribution patterns in mixed forests. Consequently, not much is known about space partitioning among the root systems of different coexisting tree species, neither with respect to the layering of the root systems in vertical direction, nor in terms of horizontal root extension and the degree of overlap between neighbouring trees (Stone and Kalisz 1991; Casper and Jackson 1997).

In this study in a broad-leaved temperate forest, we were able to identify fine roots of various tree species based on a recently developed morphological key, which enabled us to analyse the vertical and horizontal distribution of the fine root systems of different species separately. The study was conducted along a gradient from monospecific to multispecies dominated forest plots to investigate the effect of tree species diversity and/or species identity on stand fine root biomass and spatial rooting patterns.

We tested the hypotheses that (1) tree species mixture results in a spatial segregation of the fine root systems with preference of different soil layers by the species, (2) the root systems of different tree species overlap largely in horizontal direction, (3) stand fine root biomass increases with tree species diversity, and (4) fine roots of tree saplings contribute significantly to total fine root biomass in stands with abundant offspring.

\section{Materials and methods}

Study site

The study was conducted in a mature broad-leaved deciduous forest in the Hainich National Park in Thuringia (Germany). The most abundant tree species in this area is European beech (Fagus sylvatica L.), but due to former forest practice, some stands consist of up to 14 tree species. Forest plots of the more diverse categories DL 2 and DL 3 were in former times (several decades ago) managed by landowners that applied a more intense forest use than those owning the DL 1 stands, leading to the establishment of more diverse stands. However, all stands have been subjected to an only extensive forest use in the past c. 50 years and no management at all occurred since the national park was established in 1997. In the north-eastern part of the National Park, 12 study plots $(50 \mathrm{~m} \times 50 \mathrm{~m})$ were selected spanning a gradient from low diverse (monospecific) stands to forest plots dominated by several species (multi-species stands) under similar climate and soil conditions with four replicate plots per diversity level. Diversity level 1 (DL 1) plots were dominated by Fagus sylvatica (proportion of basal area $>95 \%$ ). Plots of diversity level 2 (DL 2) were formed by Fagus s., Tilia species (Tilia cordata Mill. and T. platyphyllos Scop.) and Fraxinus excelsior L. Diversity level 3 (DL 3) plots were built mainly by five tree species: Fagus, Tilia (both species), Fraxinus, Carpinus betulus L. and Acer species (Acer pseudoplatanus L. and A. platanoides L.). In some DL 3 plots, Quercus robur L., Q. petraea Liebl., Prunus avium L. and Ulmus glabra L. occurred with few individuals (Table 1).

All plots represented mature forest stands with a closed canopy and a mean tree age of about 100 years. The Fagus trees on the DL 1 plots were somewhat older (mean: 146 years), however, tree height of the canopy trees ranged between 26 and $38 \mathrm{~m}$ (Table 1). The studied stands had similar basal areas $\left(32-46 \mathrm{~m}^{2} \mathrm{ha}^{-1}\right)$. A second layer of lower sub-canopy trees was almost absent in the study plots, but small tree saplings were abundant on the forest floor. Mean tree sapling density was 31,600 individuals per hectare in the DL 1 plots, while the density in the DL 3 plots was almost fourfold higher (Mölder et al. 2009).

Mean annual precipitation in the study region was $670 \mathrm{~mm}$ and annual temperature averaged at $7.5^{\circ} \mathrm{C}$ (data 
Table 1 Above-ground stand structural properties of the 12 study plots of the three diversity levels

\begin{tabular}{|c|c|c|c|c|c|c|c|c|c|c|c|c|}
\hline & \multicolumn{4}{|l|}{ DL 1} & \multicolumn{4}{|l|}{ DL 2} & \multicolumn{4}{|l|}{ DL 3} \\
\hline & $\mathrm{a}$ & $\mathrm{b}$ & $\mathrm{c}$ & $\mathrm{d}$ & $\mathrm{a}$ & $\mathrm{b}$ & $\mathrm{c}$ & $\mathrm{d}$ & $\mathrm{a}$ & $\mathrm{b}$ & $\mathrm{c}$ & $\mathrm{d}$ \\
\hline Mean tree height of dominant trees (m) & 33.3 & 35.3 & 38.4 & 36.6 & 27.5 & 29.6 & 29.2 & 27.8 & 27.4 & 26.4 & 26.2 & 26.5 \\
\hline Stem density $\left(\mathrm{n} \mathrm{ha}^{-1}\right)$ & 428 & 216 & 220 & 224 & 436 & 532 & 776 & 660 & 392 & 332 & 468 & 484 \\
\hline Fagus sylvatica & 400 & 180 & 220 & 196 & 208 & 316 & 572 & 400 & 12 & 8 & 196 & 64 \\
\hline Fraxinus excelsior & 8 & - & - & - & 60 & 176 & 100 & 160 & 28 & 44 & 76 & 136 \\
\hline Tilia sp. & 12 & - & - & 8 & 144 & 20 & 84 & 80 & 264 & 212 & 160 & 184 \\
\hline Acer sp. & 8 & 4 & - & 20 & 24 & 12 & 20 & 16 & 32 & 24 & 20 & 32 \\
\hline Carpinus betulus & - & - & - & - & - & - & - & 4 & 36 & 36 & 16 & 44 \\
\hline Other species & - & 32 & - & - & - & 8 & - & - & 20 & 8 & - & 24 \\
\hline Basal area $\left(\mathrm{m}^{2} \mathrm{ha}^{-1}\right)$ & 46.1 & 41.2 & 35.2 & 44.0 & 32.3 & 38.8 & 45.0 & 38.9 & 35.7 & 32.4 & 40.7 & 34.6 \\
\hline Fagus sylvatica & 43.5 & 36.4 & 35.2 & 42.0 & 19.2 & 24.9 & 30.0 & 20.3 & 3.3 & 3.9 & 16.6 & 5.3 \\
\hline Fraxinus excelsior & 0.9 & - & - & - & 4.3 & 9.3 & 8.0 & 12.6 & 3.4 & 1.6 & 12.8 & 9.9 \\
\hline Tilia sp. & 1.3 & - & - & 0.1 & 6.2 & 0.7 & 5.7 & 4.5 & 19.2 & 15.2 & 6.0 & 11.2 \\
\hline Acer sp. & 0.3 & 0.2 & - & 2.2 & 2.7 & 2.4 & 1.3 & 1.3 & 2.1 & 3.5 & 3.6 & 2.6 \\
\hline Carpinus betulus & - & - & - & - & - & - & - & 0.1 & 3.6 & 6.5 & 1.8 & 4.3 \\
\hline Other species & - & 4.6 & - & - & - & 1.5 & - & - & 4.2 & 1.8 & - & 1.5 \\
\hline Number of tree saplings $\left(\mathrm{n} \mathrm{ha}^{-1}\right)$ & 11,467 & 29,867 & 4,267 & 80,800 & 220,833 & 166,667 & 190,00 & 19,500 & 117,333 & 232,500 & 90,667 & 40,000 \\
\hline
\end{tabular}

Data on basal area, stem density and mean canopy tree height from Brauns (unpublished), and number of tree saplings from Mölder et al. (2009). The data refer to the total stand (i.e. all tree individuals $>7 \mathrm{~cm}$ height). 'Other species' refers to the few individuals of the species Acer campestre (DL 3a, 3d), Prunus avium (DL 3a, 3b, 3d), Quercus petraea (DL 1b), Quercus robur (DL 3a, 3b), Sorbus torminalis (DL 3d), and Ulmus glabra (DL 2b, 3d)

from the nearby weather station Weberstedt/Hainich). The elevation of the plots was about $350 \mathrm{~m}$ a.s.1. The soils developed from triassic limestone covered by loess (minimum depth: $60 \mathrm{~cm})$. The $\mathrm{pH}\left(\mathrm{H}_{2} \mathrm{O}\right)$ in $0-10 \mathrm{~cm}$ soil depth ranged from 4.6 to 6.7. The soil type was a luvisol (IUSS Working Group WRB 2006) with stagnic properties in spring and winter and a dry period in summer. The soil texture of the mineral soil (0-30 cm) was characterised by high silt (74\%), but low sand $(<5 \%)$ content (Guckland et al. 2009). In the stands dominated by Fagus, the base saturation was lower than in the mixed stands, which is thought to be a consequence of the higher acidification potential of beech leaves. Detailed information on study plot selection and stand characteristics are given in Leuschner et al. (2009), Mölder et al. (2006), and Meinen et al. (2009).

\section{Fine root sampling}

In order to analyse biomass and spatial distribution of the fine roots, 24 sampling locations were randomly selected in each study plot. The sampling locations had a minimum distance to each other of $1 \mathrm{~m}$. Soil samples were taken in summer of 2005 and 2006 with a sharp soil corer $(3.5 \mathrm{~cm}$ in diameter) from the organic litter layer and the upper mineral soil down to $40 \mathrm{~cm}$ soil depth. Inspection of several soil pits revealed that the thickness of the mineral soil in general did not exceed $40-50 \mathrm{~cm}$ and tree fine roots occurred at low densities below $40 \mathrm{~cm}$ soil depth. The cores were divided in the $0-10,10-20,20-30$ and 30-40 $\mathrm{cm}$ soil layers. In order to extract all fine roots (diameter $<2 \mathrm{~mm}$ ) from the soil, the samples were shortly soaked in water and the roots washed out in a sieve (mesh size $0.25 \mathrm{~mm}$ ). Fine root fragments longer than $1 \mathrm{~cm}$ were collected by hand with a pair of tweezers and sorted under a stereo-microscope for live and dead fractions. Morphological parameters as the degree of cohesion of root stele and periderm, root elasticity or the total loss of the stele were used for separating live and dead roots (Persson 1978; Leuschner et al. 2001). Only data on living fine roots (i.e. fine root biomass) are reported in this article.

Based on an identification key established for the relevant tree species by Hölscher et al. (2002) and Korn (2004), we identified the roots by morphological characteristics (fine root surface structure, colour of the periderm, ramification patterns and type of mycorrhizal infection). Grass and herb roots were distinguished from tree roots by their smaller diameter, non-lignified structure and lighter colour. Fine root biomass and fine root necromass were dried at $70^{\circ} \mathrm{C}$ for $48 \mathrm{~h}$ and weighed. The data was used to analyse the vertical and horizontal distribution of the fine roots by species and to calculate the stands' total fine root biomass (unit: $\mathrm{g} \mathrm{m}^{-2}$ ).

In order to analyse the contribution of tree saplings to the stands' fine root biomass, saplings of Fagus sylvatica, 
Fraxinus excelsior and Acer pseudoplatanus were excavated next to the DL 3 plots (20 saplings per species). These three species accounted for $>90 \%$ of the total number of saplings present in the stands. For Fraxinus and Acer, saplings of three different height classes (5-20, 2040 and 40-60 cm) were sampled; for Fagus, an additional height class $(60-80 \mathrm{~cm})$ was investigated to cover the size spectrum of saplings present.

The root mass (fine roots $<2 \mathrm{~mm}$ and coarse roots $>2 \mathrm{~mm}$ in diameter) of the saplings was extracted from the excavated soil and dried $\left(70^{\circ} \mathrm{C}\right.$ for $\left.48 \mathrm{~h}\right)$. The proportion of sapling root mass in the stand total of fine root biomass was estimated from the fine root biomass data obtained by sapling excavation and the abundance of tree saplings in the respective stand (Mölder et al. 2009).

\section{Statistical analyses}

We used the asymptotic model with the equation $y=1-\beta^{d}$ (Gale and Grigal 1987) to describe the vertical decrease in fine root density with increasing soil depth, where $y$ expresses the cumulative fine root fraction contained in the soil from the surface to soil depth $d$ (in $\mathrm{cm}$ ). High $\beta$ values (ca. 0.98) indicate a large proportion of fine root biomass in a deeper soil depth, low $\beta$ values (ca. 0.90) stand for a large proportion of fine roots near the soil surface. The $\beta$ values were calculated individually for each tree species being present in the 12 plots. The regression fits were calculated with the software package Xact (version 8.03, SciLab, Hamburg, Germany).

For each sampling location, the distance to the surrounding trees was measured. In order to analyse the horizontal distribution of fine root biomass by species, linear or simple logistic regression models were used to fit root biomass data to the distance of the nearest stem of the respective species. For the calculations, only the maximum root biomass values per distance class were used (software package Xact version 8.03, SciLab, Hamburg, Germany).

All data sets on fine root mass were tested for normal distribution using a Shapiro-Wilk test. The $\beta$ values showed normal distribution and were compared between the diversity levels for each species, between the species for each diversity level, and between the stand totals by ANOVA followed by a Scheffé $f$ test. The root biomass data were nonnormally distributed and remained skewed after log or root transformation. Therefore, a Kruskal-Wallis single factor analysis of variance followed by non-parametric MannWhitney two sample $U$-tests was applied to detect significant differences in root biomass between the diversity levels for each species, between the species for each diversity level, and between the stand totals ( $P<0.05$ in all analyses). These calculations were conducted with the software package SAS, version 8.2 (SAS Institute Inc., Cary, NC, USA).

\section{Results}

Species composition of fine root biomass

Stand fine root biomass (0-40 cm depth) did not differ significantly between the three diversity levels (Fig. 1). Fine root biomass ranged between $408 \mathrm{~g} \mathrm{~m}^{-2}$ in the plots of DL 1 and $466 \mathrm{~g} \mathrm{~m}^{-2}$ in the plots of DL 2. The contribution of the tree species to the stand totals of root biomass mirrored the tree species composition of the stands. The fine root biomass of the quasi monospecific DL 1 plots consisted by $96 \%$ of Fagus roots. The root biomass in the plots of DL 2 was mainly composed of Fagus (47\%) and Fraxinus (35\%) roots, followed by roots of Tilia sp. (11\%). In contrast, fine roots of up to six species were found in the DL 3 plots. Tilia $s p$. and Fraxinus accounted for the majority of the fine root biomass in these stands (together 61\%), while Fagus, Acer sp. and Carpinus showed only minor contributions (11-13\%).

When compared to the above-ground abundance of the species (expressed as a species' contribution to total stand basal area), the abundance of the different tree species in the root samples revealed that certain species were either over- or underrepresented with their fine roots in the mixed stands. The ratio of percent fine root biomass to percent basal area was $>1$ for Fraxinus and Tilia in the DL 2 plots indicating higher below-ground than above-ground abundances (Table 2). In contrast, Fagus and Acer were underrepresented in the soil of these plots. In the DL 3 plots, the highest relative representation in the standing fine root biomass was found for Fraxinus and Acer. Tilia and Carpinus showed similar abundances above- and belowground, whereas Fagus was markedly underrepresented below-ground.

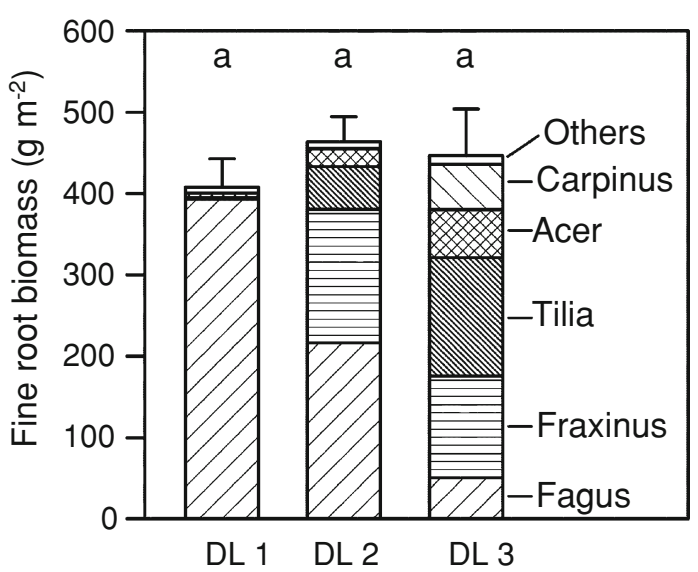

Fig. 1 Species composition of fine root biomass in the plots of the three diversity levels. Given are means +1 SE of the profile totals (0-40 cm soil depth) of four plot replicates per diversity level and 24 sampling locations per plot. Different letters indicate significant differences $(P<0.05)$ between diversity levels 
Table 2 Mean ratio of the percent contribution of a species in standing fine root biomass to its percent contribution to stand basal area in the plots of the three diversity levels $(n=4$ per diversity level)

\begin{tabular}{llll}
\hline & DL 1 & DL 2 & DL 3 \\
\hline Fagus sylvatica & $1.0 \pm 0.03 \alpha$ & $0.7 \pm 0.1 \mathrm{a} \beta$ & $0.6 \pm 0.2 \mathrm{a} \beta$ \\
Fraxinus excelsior & & $1.6 \pm 0.4 \mathrm{a} \alpha$ & $1.8 \pm 0.5 \mathrm{bc} \alpha$ \\
Tilia sp. & & $1.4 \pm 0.4 \mathrm{a} \alpha$ & $0.9 \pm 0.2 \mathrm{a} \alpha$ \\
Acer sp. & $0.8 \pm 0.2 \mathrm{a} \alpha$ & $1.8 \pm 0.1 \mathrm{c} \beta$ \\
Carpinus betulus. & & & $1.1 \pm 0.2 \mathrm{ac} \mathrm{b}$
\end{tabular}

Given are means \pm SE for the five most dominant species in the three diversity levels. Fine root data refer to soil profile totals $(0-40 \mathrm{~cm}$ depth). Different letters indicate significant differences between species (Latin letters) or diversity levels (greek letters); $P<0.05$

Fine root biomass of tree saplings

The fine root biomass of the tree saplings ranged from $1.0 \mathrm{~g} \mathrm{~m}^{-2}$ (in the DL 1 plots) to $2.2 \mathrm{~g} \mathrm{~m}^{-2}$ in the plots of DL 2 (Table 3). In contrast to the tree species composition of the DL 1 stands, the contribution of fine root biomass from Fagus saplings was remarkably low in these monospecific stands, while Acer saplings contributed half of the fine root biomass in the sapling fraction. In fact, offspring of Acer dominated sapling fine root biomass in all plots of the diversity gradient. Nevertheless, the contribution of sapling roots to the total fine root biomass of the stands was only $0.2 \%$ in the DL 1 plots, $0.5 \%$ in the DL 2 plots and $0.4 \%$ in the DL 3 plots.

\section{Vertical fine root distribution}

The abundance of tree fine roots decreased exponentially with increasing soil depth in the species-poor and also in the species-rich stands (Fig. 2). In all plots, about half of the stand total of fine root biomass was found in the upper

Table 3 Totals fine root biomass $\left(\mathrm{g} \mathrm{m}^{-2}\right)$ of tree saplings in plots of the three diversity levels estimated from allometric fine root biomass data of the saplings ( $n=20$ tree saplings per species) and sapling abundance in the plots

\begin{tabular}{llll}
\hline & DL 1 & DL 2 & DL 3 \\
\hline $\begin{array}{c}\text { Fagus } \\
\text { sylvatica }\end{array}$ & $0.22 \pm 0.13 \mathrm{a} \alpha$ & $0.43 \pm 0.17 \mathrm{a} \alpha$ & $0.13 \pm 0.03 \mathrm{a} \alpha$ \\
$\begin{array}{c}\text { Fraxinus } \\
\text { excelsior }\end{array}$ & $0.26 \pm 0.46 \mathrm{a} \alpha$ & $0.56 \pm 0.24 \mathrm{a} \alpha$ & $0.73 \pm 0.36 \mathrm{ab} \alpha$ \\
$\begin{array}{l}\text { Acer sp. } \\
\text { Stand total }\end{array}$ & $0.52 \pm 0.43 \mathrm{a} \alpha$ & $1.23 \pm 0.56 \mathrm{a} \alpha$ & $1.06 \pm 0.37 \mathrm{~b} \alpha$ \\
\hline
\end{tabular}

Given are means \pm 1 SE from four plot replicates per diversity level. Different letters indicate significant differences $(P<0.05)$ between the diversity levels for each species (greek letters), between species for each diversity level (lower case Latin letters) or between stand totals for each diversity level (Capital letters)

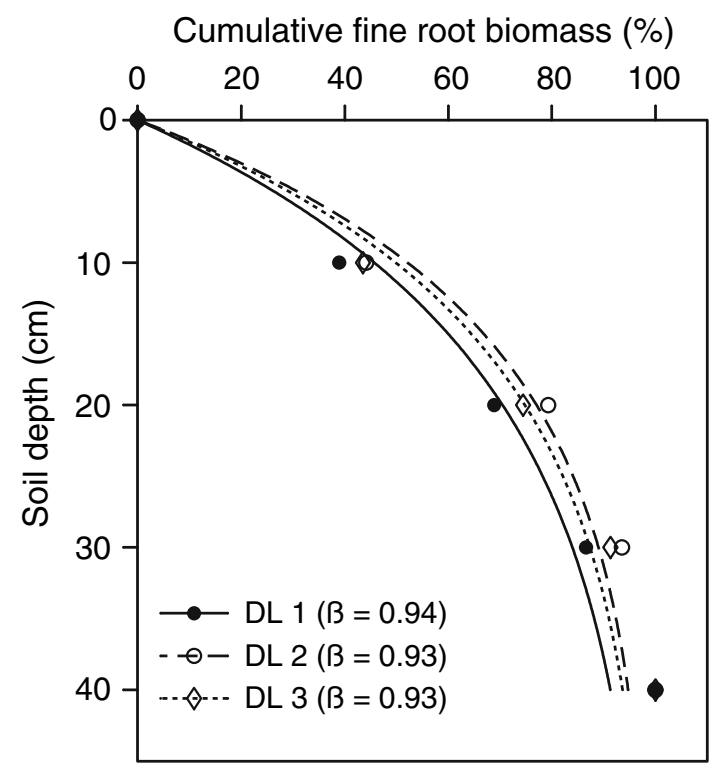

Fig. 2 Change of cumulative fine root biomass with increasing soil depth in plots of the three diversity levels (DL). Given are means of four plot replicates per diversity level and 24 sampling locations per plot. The regression equation $y=1-\beta^{d}$ (Gale and Grigal 1987) describes the change in cumulative fine root biomass fraction $(y)$ with soil depth $(d)$. The $\beta$ value indicates the degree of fine root biomass decrease with soil depth

$15 \mathrm{~cm}$ of the profile. The vertical decrease of root mass was very similar in all stands as indicated by $\beta$ values between 0.93 and 0.94 (Table 4). When the species were analysed separately, maximum $\beta$ values reached 0.95 as in the case of Carpinus in the DL 3 plots. Lowest $\beta$ values were found for Acer $s p$. in the DL 2 plots and for the infrequent species Acer campestre, Prunus avium, Ulmus glabra, and Quercus robur in the DL 3 plots (0.91 and 0.90 , respectively).

In general, the species differences and the plot differences in the $\beta$ values were very small (Fig. 3). An exception was found in the vertical fine root distribution of Fagus in the DL 2 plots, where this species had the highest fine root density in $10-20 \mathrm{~cm}$ soil depth and not at the soil surface.

\section{Horizontal fine root distribution}

The tree species differed in their patterns of horizontal fine root distribution in the mixed DL 2 and DL 3 stands (Fig. 4). The fine roots of Fagus, Fraxinus, and Acer sp. showed relatively large horizontal extensions (up to 16$19 \mathrm{~m}$ from their stems), while no fine roots of Tilia $s p$. and Carpinus were found beyond $10 \mathrm{~m}$ distance from the stems. The decrease in fine root biomass was more or less abrupt for Fagus, Tilia sp. and Carpinus. In contrast, the fine root system of Fraxinus showed a continuous and modest decrease in biomass with distance from the nearest 
Table 4 Vertical decrease of fine root biomass density with soil depth as expressed by the $\beta$ value of the equation $y=1-\beta^{d}$ (with $y=$ root biomass and $d=$ soil depth, Gale and Grigal 1987) for the tree species in plots of the three diversity levels

\begin{tabular}{llll}
\hline Species & DL 1 & DL 2 & DL 3 \\
\hline Fagus sylvatica & $0.94 \pm 0.007 \alpha$ & $0.94 \pm 0.002 \mathrm{a} \alpha$ & $0.93 \pm 0.02 \mathrm{a} \alpha$ \\
Fraxinus excelsior & & $0.92 \pm 0.005 \mathrm{ab} \alpha$ & $0.92 \pm 0.004 \mathrm{a} \alpha$ \\
Tilia sp. & & $0.92 \pm 0.002 \mathrm{ab} \alpha$ & $0.93 \pm 0.006 \mathrm{a} \alpha$ \\
Acer sp. & & $0.91 \pm 0.008 \mathrm{~b} \alpha$ & $0.92 \pm 0.008 \mathrm{a} \alpha$ \\
Carpinus betulus & & $0.95 \pm 0.008 \mathrm{a}$ \\
Other species & & & $0.90 \pm 0.02 \mathrm{a}$ \\
Stand total & $0.94 \pm 0.007 \mathrm{~A}$ & $0.93 \pm 0.005 \mathrm{~A}$ & $0.93 \pm 0.006 \mathrm{~A}$ \\
\hline
\end{tabular}

Given are means $\pm 1 \mathrm{SE}$ of four plot replicates per diversity level and 24 sampling locations per plot. Different letters indicate significant differences $(P<0.05)$ between diversity levels for each species (greek letters), between species for each diversity level (lower case Latin letters) or between stand totals for each diversity level (capital letters)

Fig. 3 Change of fine root density with soil depth for the different tree species present in the plots of the three diversity levels (DL). Given are means of four plot replicates per diversity level and 24 sampling locations per plot. "Others" refers to fine root biomass of the infrequent species Acer campestre, Prunus avium, Ulmus glabra, Quercus petraea and $Q$. robur

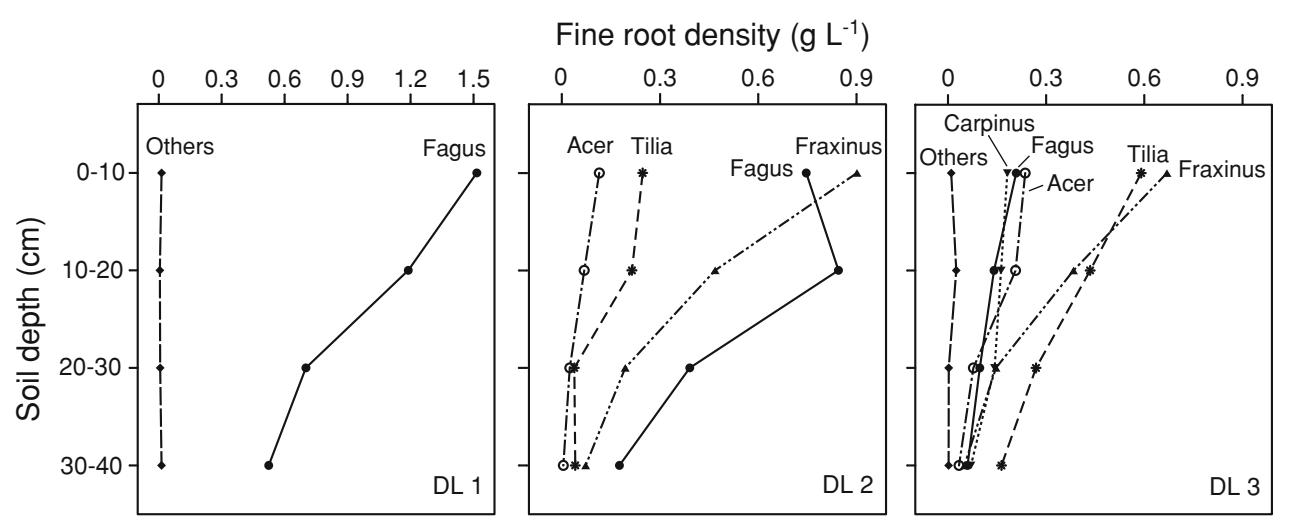

stem. The fine root biomass of Acer sp. displayed an only weak dependence on distance.

We found a remarkably large overlap of the fine root systems of different species not only in the mixed DL 2 and DL 3 stands, but also in the DL 1 stands, where beech contributed at least $95 \%$ to the stands' basal area. The roots of the infrequent tree species were admixed to beech roots in $25 \%$ of the soil samples investigated in the quasi monospecific DL 1 stands, while roots of beech occurred without presence of another species in $75 \%$ of the samples (Fig. 5). The samples of the DL 2 plots contained roots of up to five tree species with the majority (76\%) being colonised by two or three species. In the most species-rich DL 3 plots, $45 \%$ of the samples contained three root species, another $49 \%$ either two or four species.

\section{Discussion}

Fine root biomass of mixed forests: evidence for 'below-ground overyielding'?

Contrary to our initial hypothesis, the profile totals of fine root biomass (0-40 $\mathrm{cm}$ depth) did not differ significantly between forest stands with a single or a higher number of dominant tree species. In all plots of our study, fine root biomass totals ranged between $408 \mathrm{~g} \mathrm{~m}^{-2}$ (DL 1 plots) and $466 \mathrm{~g} \mathrm{~m}^{-2}$ (DL 2 plots) with the difference not being significant. These values may be close to the totals of the entire soil profile, because the lower soil horizons with a high bulk density contained an only small fine root biomass. In fact, Leuschner and Hertel (2002) found a mean fine root biomass total of $482 \mathrm{~g} \mathrm{~m}^{-2}(0-100 \mathrm{~cm}$ profile) for 60 broadleaved forests in a meta-analysis for the temperate zone.

In theory, niche complementarity of the root systems of coexisting tree species could lead to a higher fine root biomass in mixed forests compared to monospecific stands of the respective tree species. For example, roots of certain tree species may penetrate into lower mineral soil layers, thereby exploring additional soil volume, or they might specialise on preferential rooting in the organic layer which may not be explored in a comparable intensity by other tree species (e.g. Loreau 1998; Grierson and Adams 1999; Pate and Bell 1999; Ewel and Mazzarino 2008). A higher fine root biomass in multi-species compared to monospecific stands resembles the 'overyielding' phenomenon, which is observed e.g. in artificial grasslands (Hector et al. 1999; Roscher et al. 2005), when mixed cultures have a higher above-ground phytomass production than any monoculture of the constituting species. Clearly, data on fine root 


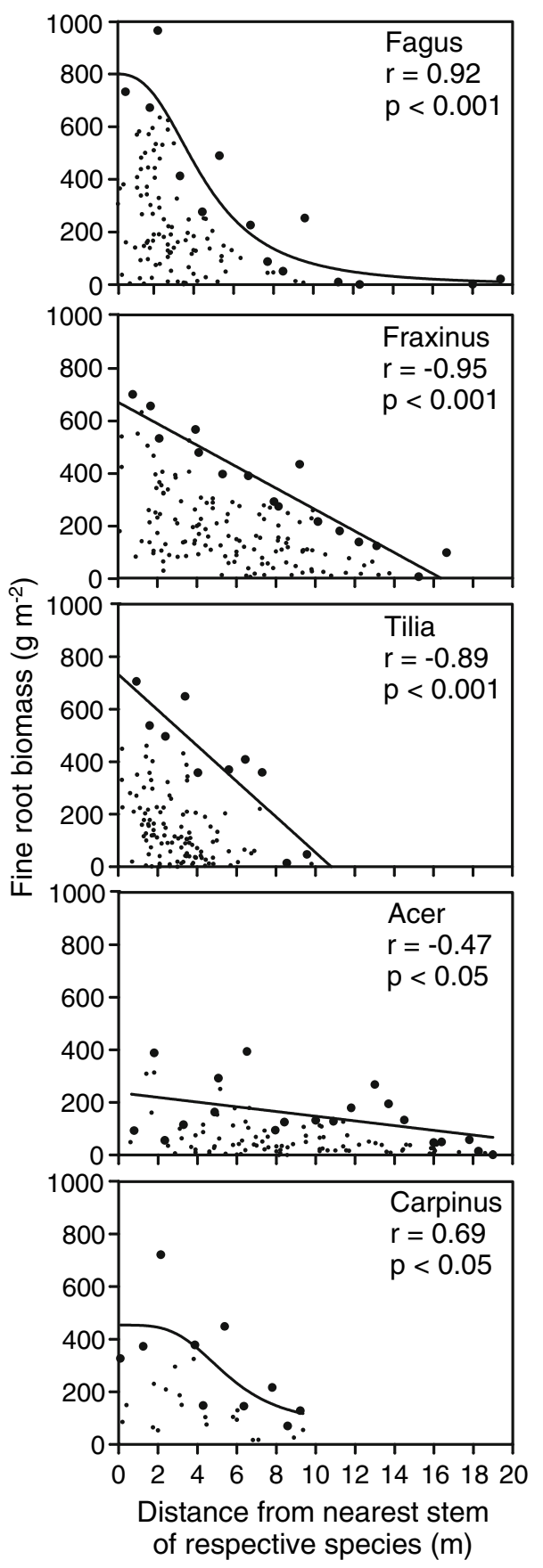

Fig. 4 Change of fine root biomass ( $0-40 \mathrm{~cm}$ profile) with increasing stem distance of the most abundant tree species in the DL 2 and DL 3 plots. Maximum fine root biomass values are indicated with large dots. Given are fits of the non-linear logistic function $y=a+(b-$ $a) /\left(1+(x / c)^{d}\right)$ or a linear regression model of maximum fine root biomass on distance from the nearest stem of the respective species

biomass and hay yield are not directly comparable, because only the latter refers to productivity. Nevertheless, given the large methodological problems associated with fine root production measurement, standing fine root biomass may serve as a first approximation of below-ground productivity in forests.

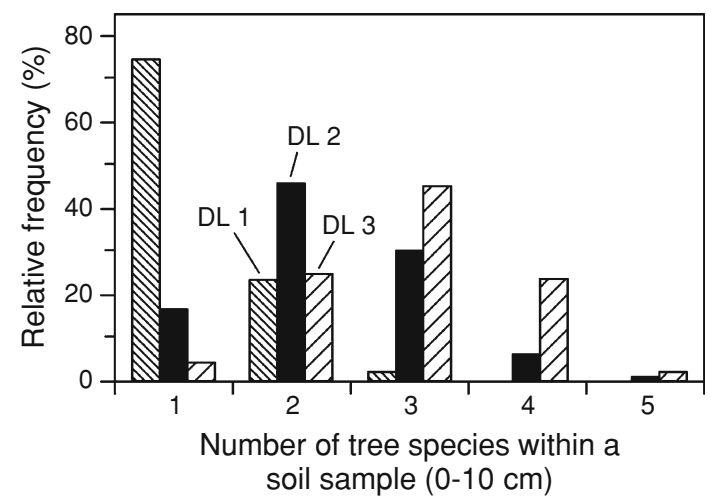

Fig. 5 Relative frequency of soil samples $(0-10 \mathrm{~cm})$ with fine roots of $1,2,3,4$ or 5 tree species in plots of the three diversity levels (four plot replicates per diversity level and 24 sampling locations per plot)

We are aware of only few studies including the present one, which compared fine root biomass of monospecific and mixed temperate forests on similar soil or patches of a forest differing in tree species diversity. While six studies compared one- and two-species stands, the study by Rewald and Leuschner (2009) together with the present one are the only studies, which referred to species-rich stands with more than four tree species. These eight studies produced inconsistent results with respect to 'belowground overyielding'. Schmid (2002) found a higher fine root biomass in two-species (spruce/beech) stands compared to monospecific stands, while three other studies reported lower biomasses in mixtures (Morgan et al. 1992: larch/pine; Hendriks and Bianchi 1995: beech/Douglas fir; Bolte and Villanueva 2006: spruce/beech). Brandtberg et al. (2000) and Leuschner et al. (2001), on the other hand, observed a similar fine root mass in one- and two-species stands (spruce/birch and beech/oak, respectively). The study by Rewald and Leuschner (2009) compared forest patches, where roots of one to four tree species (beech/ hornbeam/oak/lime) coexisted in the soil, and provided only weak evidence of the existence of a higher fine root mass in mixed patches. By comparing monospecific stands with stands of three to five species, our study similarly found no conclusive evidence of higher root biomass in the species-rich stands. This is all the more interesting since some authors have emphasized that diversity effects such as overyielding might be caused more by functional properties of particular species rather than by species richness per se (Hooper and Vitousek 1997; Hooper and Dukes 2004). In fact, the tree species present in the more species-rich stands in our study showed some pronounced functional differences (e.g. in VA vs. EC mycorrhizal status, in specific root surface area, and in root tip frequency; Meinen et al. 2009) that actually did not lead to overyielding in terms of standing fine root biomass. 
In conclusion, not much evidence has accumulated yet for a higher fine root biomass in temperate mixed forests compared to pure stands. On the other hand, several studies found indications of a spatial segregation of the fine root systems of different species in mixed forests (e.g. Schmid and Kazda 2002; Bennett et al. 2002; Bolte and Villanueva 2006), irrespective of elevated or reduced root biomasses in mixtures. In our study, we compared the vertical distribution of fine root biomass with the exponential model of Gale and Grigal (1987) and found very similar patterns for the overall distribution pattern of 1-, 3- and 5-species stands, but also for the different species being present in the stands. All species showed exponents of the exponential equation ( $\beta$ values) of $0.92-0.95$, which indicates no systematic difference in the vertical soil exploration strategies of the species. This finding is in clear contrast to our initial hypothesis. We speculate that the specific soil conditions may have contributed to the uniform root biomass/ depth relations in our study: bulk density was rather high in the clayey soil and increased with depth, thereby hindering deep root penetration.

\section{Horizontal fine root distribution and species overlap}

The fine root systems had a far larger horizontal extension than the corresponding tree crowns in the mixed stands. With an estimated maximum diameter of the fine root system of $20 \mathrm{~m}$ (Carpinus and Tilia) to $40 \mathrm{~m}$ (Fagus and Acer), trees of these species may spread their fine roots over an area of ca. $300 \mathrm{~m}^{2}$ and up to $1,200 \mathrm{~m}^{2}$, which is roughly 5-20 times the size of the corresponding crown projection area (Frech et al. 2003; Utschig and Küsters 2003; Grote 2003; Hemery et al. 2005; Frech 2006). While Hölscher et al. (2002) found a maximum horizontal extension of only ca. $8 \mathrm{~m}$ for fine roots of Fagus and Tilia, Hertel (1999) reported a maximum horizontal distance of Quercus fine roots from the nearest stem of $>12 \mathrm{~m}$, and Rewald and Leuschner (2009) found a maximum root extension of even $30 \mathrm{~m}$ in the case of Tilia trees.

For Fraxinus, Tilia and Acer, we found a gradual decrease in fine root density with increasing stem distance within a radius of $10 \mathrm{~m}$ or more, but not a strict stemcentered distribution pattern as it was observed, for example, in spruce forests by Bédéneau and Auclair (1989) and Nielsen and Mackenthun (1991). Only in the case of Carpinus and Fagus trees growing in mixed stands, fine root biomass showed a steep decrease within an 8 m-radius around the stems. Depending on tree species, the decrease was best described either by a linear or a sigmoid equation. The Acer species showed a remarkable rooting pattern by maintaining only rather low root densities in the mixed stands, which, however, extended over a large area and reached maximum stem distances of up to $20 \mathrm{~m}$.
As presumed in our hypothesis, the data from our study showed a high degree of root system overlap in all mixed stands, and even did so in the pure beech stands where the infrequent species intermingled largely with the dominant beech roots. This is in agreement with data obtained in two-species beech-oak stands where both tree species were present in more than $95 \%$ of all root samples (Büttner and Leuschner 1994; Leuschner et al. 2001). Hence, we found no indications of a pronounced horizontal segregation of the trees' fine root systems in these stands.

Are there indications of root competition between adults and saplings?

High densities of fine root biomass per soil volume could potentially lead to strong competition between co-existing tree species and also between adult and juvenile trees. For example, Rysavy (1992) and Wagner (1999) discussed the potential role of high root densities of ash saplings for beech regeneration in mixed stands on calcareous soils. They concluded from their findings that competitioninduced alteration of the vertical rooting pattern of juvenile beech trees may result in hampered water supply to beech saplings. In our study, total fine root biomass (adults plus saplings) exceeded $1 \mathrm{~g} \mathrm{~L}^{-1}$ in the topsoil of certain plots, which could have a negative effect on sapling survival. However, tree saplings occurred in very high numbers in many plots, locally exceeding $220,000 \mathrm{ha}^{-1}$. The most common trees in the sapling layer were Acer species which dominated even in the monospecific beech stands, but the contribution of sapling fine root biomass was low in all cases, never exceeding $1 \%$ of total fine root biomass. This finding is in marked contrast to our initial presumption that tree saplings may contribute significantly to the fine root biomass stand totals, hence indicating that root competition is not a key factor determining the success of rejuvenation in these stands.

\section{Conclusions}

We could not detect significant complementarity in the rooting patterns of the different tree species in the mixed stands of our study. Hence, increasing tree species diversity did not lead to higher standing fine root biomass in more diverse stands producing no evidence of 'below-ground overyielding' in terms of root biomass. A certain degree of below-ground niche complementarity in terms of rooting space occupation may well exist in a number of mixed forests, but we conclude from our findings that this seems not to be a frequent or even universal phenomenon. This is in agreement with a conclusion drawn by Ewel and Hiremath (2005) for tropical forests emphasizing that 
belowground complementarity among tree species is rare due to genetic constraints of root system development. Systematic investigations in a larger number of forests differing in tree species diversity are needed to clarify the importance of functional niche complementarity in the fine root system among species and to show, under which circumstances it may result in 'overyielding' in terms of fine root biomass and productivity.

Acknowledgments This study is part of the postgraduate studies program Graduiertenkolleg 1086 "The role of biodiversity for biogeochemical cycles and biotic interactions in temperate deciduous forests". The funding of this study by DFG (Deutsche Forschungsgemeinschaft) and the financial support of the RISE (Research Internships in Science and Engineering) scholarship for Nicholas T. Ryan by DAAD (Deutscher Akademischer Austauschdienst) is gratefully acknowledged. We appreciate the permission to conduct the study in the Hainich National Park and thank all participants of the Graduiertenkolleg for excellent teamwork. Data of forest stand parameters were kindly provided by Mascha Brauns, Karl Maximilian Daenner, Anja Guckland, Andreas Mölder and Inga Schmidt.

Open Access This article is distributed under the terms of the Creative Commons Attribution Noncommercial License which permits any noncommercial use, distribution, and reproduction in any medium, provided the original author(s) and source are credited.

\section{References}

Bauhus J, Khanna PK, Menden N (2000) Aboveground and belowground interactions in mixed plantations of Eucalyptus globulus and Acacia mearnsii. Can J For Res 30:1886-1894. doi: 10.1139/cjfr-30-12-1886

Bédéneau M, Auclair D (1989) The study of tree fine root distribution and dynamics using a combined trench and observation window method. Ann Sci For 46:283-290. doi:10.1051/forest:19890307

Bennett JN, Andrew B, Prescott CE (2002) Vertical fine root distributions of western redcedar, western hemlock, and salal in old-growth cedar-hemlock forests on northern Vancouver Island. Can J For Res 32:1208-1216. doi:10.1139/x02-034

Bolte A, Villanueva I (2006) Interspecific competition impacts on the morphology and distribution of fine roots in European beech (Fagus sylvatica L.) and Norway spruce (Picea abies (L.) Karst.). Eur J For Res 125:15-26. doi:10.1007/s10342-005-0075-5

Brandtberg PO, Lundkvist H, Bengtsson J (2000) Changes in forestfloor chemistry caused by a birch admixture in Norway spruce stands. For Ecol Manage 130:253-264. doi:10.1016/S0378-1127 (99)00183-8

Büttner V, Leuschner C (1994) Spatial and temporal patterns of fine root abundance in a mixed oak-beech forest. For Ecol Manage 70:11-21. doi:10.1016/0378-1127(94)90071-X

Cardinale BJ, Wright JP, Cadotte MW, Caroll IT, Hector A, Srivastava DS, Loreau M, Weis JJ (2007) Impacts of plant diversity on biomass production increase through time because of species complementarity. Proceedings of the National Academy of Science USA, vol 104, pp 18123-18128

Casper BB, Jackson RB (1997) Plant competition underground. Annu Rev Ecol Syst 28:545-570. doi:10.1146/annurev.ecolsys.28.1.545

Droppelmann KJ, Ephrath JE, Berliner PR (2000a) Tree/crop complementarity in an arid zone runoff agroforestry system in northern Kenya. Agroforest Syst 50:1-16
Droppelmann KJ, Lehmann J, Ephrath JE, Berliner PR (2000b) Water use efficiency and uptake patterns in a runoff agroforestry system in an arid environment. Agroforest Syst 49:223-243

Ewel JJ (1999) Natural systems as models for the design of sustainable systems of land use. Agroforest Syst 45:1-21

Ewel JJ, Hiremath AJ (2005) Plant-plant interactions in tropical forests. In: Burslem DFRP, Pinard MA, Hartley SE (eds) Biotic interactions in the tropics: their role in maintenance of species diversity. Cambridge University Press, Cambridge, UK, pp 3-34

Ewel JJ, Mazzarino MJ (2008) Competition from below for light and nutrients shifts productivity among tropical species. Proceedings of the National Academy of Science USA, 105:18836-18841

Frech A (2006) Walddynamik in Mischwäldern des Nationalparks Hainich. PhD thesis, University of Göttingen

Frech A, Leuschner C, Hagemeier M, Hölscher D (2003) Nachbarschaftsbezogene Analyse der Kronenraumbesetzung von Esche, Hainbuche und Winterlinde in einem artenreichen Laubmischwald (Nationalpark Hainich, Thüringen). Forstwissenschaftliches Centralblatt 122:22-35

Gale MR, Grigal DF (1987) Vertical root distributions of northern tree species in relation to successional status. Can J For Res 17:829-834. doi:10.1139/x87-131

Grierson PF, Adams MA (1999) Nutrient cycling and growth on forest ecosystems of south western Australia. Relevance to agricultural landscapes. Agroforest Syst 45:215-244

Grote R (2003) Estimation of crown radii and crown projection area from stem size and tree position. Ann For Sci 60:393-402

Guckland A, Brauns M, Flessa H, Thomas FM, Leuschner C (2009) Acidity, nutrient stocks and organic matter content in soils of a temperate deciduous forest with different abundance of European beech (Fagus sylvatica L.). J Plant Nutr Soil Sci (in press)

Hector A, Schmid B, Beierkuhnlein C, Caldeira MC, Diemer M, Dimitrakopoulos PG, Finn JA, Freitas H, Giller PS, Good J, Harris R, Högberg P, Huss-Danell K, Joshi J, Jumpponen A, Körner C, Leadley PW, Loreau M, Minns A, Mulder CPH, O’Donovan G, Otway SJ, Pereira JS, Prinz A, Read DJ, Scherer-Lorenzen M, Schulze ED, Siamantziouras ASD, Spehn EM, Terry AC, Troumbis AY, Woodward FI, Yachi S, Lawton JH (1999) Plant diversity and productivity experiments in European grasslands. Science 286:1123-1127. doi:10.1126/science.286.5442.1123

Hemery GE, Savill PS, Pryor SN (2005) Applications of the crown diameter-stem diameter relationship for different species of broadleaved trees. For Ecol Manage 215:285-294

Hendriks CMA, Bianchi FJJA (1995) Root density and root biomass in pure and mixed forest stands of Douglas-fir and Beech. Neth J Agric Sci 43:321-331

Hertel D (1999) Das Feinwurzelsystem von Rein- und Mischbeständen der Rotbuche: Struktur, Dynamik und interspezifische Konkurrenz. Ph.D. thesis, University of Göttingen, Dissertationes Botanicae, Stuttgart

Hölscher D, Hertel D, Leuschner C, Hottkowitz M (2002) Tree species diversity and soil patchiness in a temperate broad-leaved forest with limited rooting space. Flora 197:118-125

Hooper DU, Dukes JS (2004) Overyielding among plant functional groups in a long-term experiment. Ecol Lett 7:95-105

Hooper DU, Vitousek PM (1997) The effects of plant composition and diversity on ecosystem processes. Science 277:1302-1305. doi:10.1126/science.277.5330.1302

Hooper DU, Chapin FS, Ewel JJ, Hector A, Inchausti P, Lavorel S, Lawton JH, Lodge DM, Loreau M, Naeem S, Schmid B, Setälä H, Symstad AJ, Vandermeer J, Wardle DA (2005) Effects of biodiversity on ecosystem functioning: a consensus of current knowledge. Ecol Monogr 75:3-35

Huxley PA, Pinney A, Akunda E, Muraya P (1994) A tree/crop interface orientation experiment with a Grevillea robusta hedgerow and maize. Agroforest Syst 26:23-45 
Jolliffe PA (1997) Are mixed populations of plant species more productive than pure stands? Oikos 80:595-602

Korn S (2004) Experimentelle Untersuchung der Wasseraufnahme und der hydraulischen Eigenschaften des Wurzelsystems von sechs heimischen Baumarten. Ph.D. thesis. University of Goettingen. http://webdoc.sub.gwdg.de/diss/2004/korn

Leuschner C, Hertel D (2002) Fine root biomass of temperate forests in relation to soil acidity and fertility, climate, age and species. Prog Bot 64:405-438

Leuschner C, Hertel D, Coners H, Büttner V (2001) Root competition between beech and oak: a hypothesis. Oecologia 126:276-284. doi: $10.1007 / \mathrm{s} 004420000507$

Leuschner C, Jungkunst HF, Fleck S (2009) Studying the functional role of tree diversity in forests: the pros and cons of synthetic stands and across-site comparisons in established forests. Basic Appl Ecol 10:1-9. doi:10.1016/j.baae.2008.06.001

Loreau M (1998) Biodiversity and ecosystem functioning: a mechanistic model. Proceedings of the National Academy of Science USA, vol 95, pp 5632-5636

Loreau M, Hector A (2001) Partitioning selection and complementarity in biodiversity experiments. Nature 412:72-76. doi: $10.1038 / 35083573$

Meinen C, Hertel D, Leuschner C (2009) Biomass and morphology of fine roots in temperate broad-leaved forests differing in tree species diversity: is there evidence of below-ground overyielding? Oecologia (in press)

Menalled FD, Kelty MJ, Ewel JJ (1998) Canopy development in tropical tree plantations: a comparison of species mixtures and monocultures. For Ecol Manage 104:249-263

Mölder A, Bernhardt-Römermann M, Schmidt W (2006) Forest ecosystem research in Hainich National Park (Thuringia): first results on flora and vegetation in stands with contrasting tree species diversity. Waldoekologie 3:83-99

Mölder A, Bernhardt-Römermann M, Schmidt W (2009) Vielfältige Baumschicht—reichhaltige Verjüngung? Zur Naturverjüngung von artenreichen Laubwäldern im Nationalpark Hainich. Allg Forst Jagdzeitung 180:76-87

Morgan JL, Campbell JM, Malcolm DC (1992) Nitrogen relations of mixed-species stands on oligotrophic soils. In: Cannell MGR, Malcolm DC, Robertson PA (eds) The ecology of mixed-species stands of trees. Blackwell, London, pp 65-85

Nielsen CCN, Mackenthun G (1991) Spatial variation of fine root biomass intensity in forest soils related to stand density: a numerical-method estimating the root-intensity-bell around single trees. Allg Forst Jagdzeitung 162:112-119

Pate JS, Bell TL (1999) Application of the ecosystem mimic concept to the species-rich Banksia woodlands of western Australia. Agroforest Syst 45:303-341

Persson H (1978) Root dynamics in a young Scots pine stand in Central Sweden. Oikos 30:508-519. doi:10.2307/3543346
Rewald B, Leuschner C (2009) Belowground competition in a broadleaved temperate mixed forest-pattern analysis and experiments in a four-species stand. Eur J For Res. doi:10.1007/ s10342-009-0276-4

Roscher C, Temperton VM, Scherer-Lorenzen M, Schmitz M, Schumacher J, Schmid B, Buchmann N, Weisser WW, Schulze ED (2005) Overyielding in experimental grassland communities: irrespective of species pool or spatial scale. Ecol Lett 8(4):419429. doi:10.1111/j.1461-0248.2005.00736.x

Rysavy T (1992) Vereschung-Ursachen und Möglichkeiten ihrer Vermeidung. Ph.D. thesis. Göttingen, University of Goettingen

Scherer-Lorenzen M, Schulze ED, Don A, Schumacher J, Weller E (2007) Exploring the functional significance of forest diversity: a new long-term experiment with temperate tree species (BIOTREE). Perspect Plant Ecol Evol Syst 9:53-70

Schmid I (2002) The influence of soil type and interspecific competition on the fine root system of Norway spruce and European beech. Basic Appl Ecol 3:339-346. doi:10.1078/14391791-00116

Schmid I, Kazda M (2002) Root distribution of Norway spruce in monospecific and mixed stands on different soils. For Ecol Manage 159:37-47. doi:10.1016/S0378-1127(01)00708-3

Spehn EM, Joshi J, Schmid B, Diemer M, Körner C (2000) Aboveground resource use increases with plant species richness in experimental grassland ecosystems. Funct Ecol 14:326-337. doi: 10.1046/j.1365-2435.2000.00437.x

Stone EL, Kalisz PJ (1991) On the maximum extent of tree roots. For Ecol Manage 46:59-102. doi:10.1016/0378-1127(91)90245-Q

Tilman D, Wedin D, Knops J (1996) Productivity and sustainability influenced by biodiversity in grassland ecosystems. Nature 379:718-720. doi:10.1038/379718a0

Tilman D, Lehman CL, Thomson KT (1997) Plant diversity and ecosystem productivity: theoretical considerations. Proc Natl Acad Sci USA 94:1857-1861. doi:10.1073/pnas.94.5.1857

Utschig H, Küsters E (2003) Wachstumsreaktionen der Buche (Fagus sylvatica (L.)) auf Durchforstungen-130-jährige Beobachtung des Durchforstungsversuches Elmstein 20. Forstwissenschaftliches Centralblatt 122:389-409

Vitousek PM, Hooper DU (1993) Biological diversity and terrestrial ecosystem biogeochemistry. In: Schulze E-D, Mooney HA (eds) Biodiversity and ecosystem function. Springer, Berlin, pp 3-14

von Felten S, Schmid B (2008) Complementarity among species in horizontal versus vertical rooting space. J Plant Ecol 1:33-41

Yachi S, Loreau M (2007) Does complementary resource use enhance ecosystem functioning? A model of light competition in plant communities. Ecol Lett 10:54-62

Wagner S (1999) Ökologische Untersuchungen zur Initialphase der Naturverjüngung in Eschen-Buchen-Mischbeständen. Sauerländer's Verlag, Frankfurt am Main 